\title{
An investigation on the lack of emotion in College English Network Teaching
}

\author{
TIAN Pinjing 1, a \\ ${ }^{1}$ Jilin Business and Technology College, Changchun 130000, China \\ aemail: tianpinjingj|@163.com
}

Keywords: Network platform; network course; College English teaching; network teaching

\begin{abstract}
With the rapid development of modern educational technology, based on the network teaching activities continue to enhance. How to give full play to the advantages of network technology to carry out college English network teaching is the current college English teaching reform project. In this paper, combined with the characteristics of College English teaching network, discusses the network platform construction of the necessity and importance of the development and application of network platform system function.
\end{abstract}

\section{Introduction}

With the rapid development of computer technology and network technology, network education as a new education method provides a new idea, the rich educational resources and necessary software and hardware environment support for China's education reform. Compared with the traditional education, network education has improved the technical content of education, promoted the change of teacher's role, strengthened the students' main body position, and is conducive to the cultivation of students' ability and quality.

Network education is closely related to the reform of Public English teaching. With modern information technology, especially network technology for the support of the new teaching model create virtual teaching environment, providing a lot of information resources, make the teaching is not restricted by time and space, for individual students to learning[1], autonomous learning to create the conditions.

But with a certain network environment support is not equal to foreign language teachers will be able to successfully carry out online teaching. One of the reasons is that network teaching is not only on the Internet a one-way release information of foreign language teaching, language resources transportation, more important is between teachers and students, students and students to two-way interaction and communication on the Internet. In order to achieve this goal, it is needed to develop a network specific tool and design interactive program. However, at present, the majority of foreign language teachers know little about computer and network technology, it is difficult to realize the development of network tools. In this situation, it is urgent to build a network teaching platform, the complexity of the program design, to provide a concise tool support for foreign language teachers in the implementation of online teaching. The network platform plays an extremely important role in College English teaching. In a sense, in the case of the network environment, the network teaching is the key to the construction of the network teaching platform and play the function of the platform, which is a prerequisite for foreign language teachers to set up the network courses.

Usually the network teaching platform is built on the basis of the general Internet / Intranet, which is composed of a software system which is designed to provide a comprehensive service based on the two-way multimedia communication network teaching. Its main components are: network teaching system, courseware development system and teaching resource management system, etc.. A related system has its specific function, foreign language teachers can according to the task of teaching and the teaching characteristics, with some of the tools in the network platform to provide and use system function effectively, to carry out the remote teaching. Teaching management system can ensure that the teaching is more efficient and standardized. 


\section{Network courseware on demand and network teaching live broadcast}

The network courseware on demand and the live broadcast of the network are realized through the teaching system of the network platform. The network teaching system is a system software which provides the network teaching service, which can utilize the resources of the foreign language teaching reasonably and effectively under the support of the teaching management system.

In order to make the teaching content more vivid, more intuitive, foreign language teachers often make or buy some teaching demonstration courseware. One of the functions of the network platform is to play audio and video courseware, and synchronous playback of teachers with point power or flash production of speech or other relevant information such as: text background, synchronous practice, self testing, etc.. Some data can also be stored in the server. Students in the client terminal can synchronize information on demand for teachers, can also be suspended to a certain period of time to access the information provided by the teacher.

The focus of network teaching is to develop high quality network courseware (courseware web-based). The ideal network courseware should not only have rich learning content, strong openness and interactivity, but also should design a comprehensive teaching management function to monitor the students' learning situation. But the ability to make high quality courseware is the network development tool of professional technology and courseware, and the general foreign language teachers do not have these conditions. One of the functions of the network teaching platform is to provide a simple and practical network courseware development tool for foreign language teachers, to reduce the technical difficulty of the courseware development, and to simplify the process of developing the network courseware for teachers. For example: the introduction of multimedia material can be directly processed and adjusted to quickly generate the network courseware, online publishing for students on demand[2].

With the increase of the types of English teaching network courseware, the courseware will continue to increase the click rate. Students can in any location on campus (as long as there is a computer), in accordance with their own timetable, on demand to learn content, which gives students to learn to create an excellent condition.

In this situation, it is urgent to build a network teaching platform, the complexity of the program design, to provide a concise tool support for foreign language teachers in the implementation of online teaching. The network platform plays an extremely important role in College English teaching. In a sense, in the case of the network environment, the network teaching is the key to the construction of the network teaching platform and play the function of the platform, which is a prerequisite for foreign language teachers to set up the network courses.

Network teaching is completed in a live classroom. A different position of the camera is set in the direct broadcast room, and the teaching activities of teachers and students are different from different angles. The network platform is provided with an operating table, and the technical personnel are responsible for the taking and switching of the lens. Different from the courseware on demand, live content is not broadcast prior storage of video information, but directly transmitted to the students to play. In order to improve the quality of live, teachers must advance with the technical staff to discuss, common design lecture script (Teaching), taped in order to achieve the best results. Conditional schools can be more than a few live classroom, the same or different levels of foreign language courses in the audio and video streaming through the broadcast server to other classroom communication. Students can watch a class at different locations of the lecture live, you can also switch to a different scene.

The situation of teachers in the class can also be implemented in non real time on demand. Technical personnel for the collection of the material necessary to edit the use of compatible format stored in the server for students on demand.

The remarkable characteristic of the network teaching is that the students and the students can not be restricted in time and space to establish the effective open environment on the Internet. Teachers and students use online teaching tools such as: Email, BBS, Chatroom, etc. based on the text of the exchange of tools for synchronous or asynchronous learning and counseling. The network platform can realize the function of classroom interaction between teachers and students in 
the broadcast process. In the network classroom, but also through the audio and video conferencing system to provide graphics, voice, video and other multimedia support, image, intuitive performance of teachers and students to communicate with each other remote scene. Teachers can ask questions or answer students' questions to the students in the classroom and the viewing room, and vice versa. This makes the network English classroom a place for teachers and students to interact in real sense[3]. This kind of instant on-line interaction can help teachers to understand students' learning situation in a timely manner, and it is helpful for teachers to carry out the teaching of human nature. In particular, it is worth mentioning is: a live room can be connected with a number of viewing room, the teacher can see through the switch screen to see the student's situation, to facilitate the quality of teachers to control the students. At the same time, because of the selection of excellent teachers to engage in direct seeding, so that the limited resources of teachers have been optimized to improve the effectiveness of teaching.

\section{Comprehensive evaluation of English Network Teaching}

Teaching evaluation is an important link in the teaching process. The teaching evaluation is mainly done by manually, which is time-consuming and inaccurate. Network platform of evaluation system can not only test, analysis and record the students' final exam, and for students usually complete the online learning task to carry out comprehensive assessment, provide reliable data for transitional assessment and summative assessment.

Network comprehensive evaluation software system has the function of network test questions, test generation and test result analysis. Teachers can according to the requirements of the curriculum organization generated papers, change the exam questions, distribution of the proportion of subjective and objective questions, outstanding test of key point and the difficulty. In addition, the system can be the test results were statistically analyzed, and the analysis to the question of difficulty, the reliability and discrimination, to help teachers understand the examination paper quality, problems existing in the students' learning diagnosis, while carefully study the information obtained in the examination of teaching backwash backwash effect.

Recommended by the Ministry of education of the 4 sets of teaching software system is designed with student self testing function. Students Online Autonomous Learning

Teaching materials should be set by the system of each unit and level of testing, the system automatically records the student's test results. Also network examination database stored tens of thousands of 1-4 level questions, students can in any learning terminal, through the browser test input requirements and evaluation system can automatically from the paper selected questions composition conform to the intent test papers for self-test[4].

\section{Teaching resource management and resource sharing}

The biggest advantage of network teaching is the rational allocation and sharing of teaching resources. In order to exert the advantage of network teaching better, will obtain the teaching resources to carry on the systematic and scientific classification, storage in a variety of teaching database, component into a unified teaching resource library, the resource management system of comprehensive management. The teaching resource database includes the multimedia material database, the examination questions material database, the network courseware database, the document database and so on. All of these resources are built with index information. In order to quickly search, browse and access.

The sharing of teaching resources is the biggest characteristic of network teaching. The resource management system of the teaching platform can connect each learning terminal through the campus network, form a huge information network (see chart). In particular, it should be pointed out that: the digital network voice lab is an important component of the teaching platform. Each voice room has a network interface, and the platform is connected with the voice room through the campus network, and can realize various functions under the control of the management system:

(1) the teaching function of the traditional voice room. Teachers can carry out demonstration 
teaching, two-way dialogue, group activities, electronic hands and classroom tests, etc..

(2) students' autonomous learning and self testing function. Students can request the local server and the campus network to share the resources of the server in the listening or video information through the terminal display. Students can independent redeployment of resources on the server open questions in the examination paper for self-test, after the completion of the examination system of automatic marking score.

(3) electronic lesson preparation. The teacher may call the local resource library, the campus network and the multimedia data of the external equipment to edit, make the lesson plan or the electronic paper, and deposit in the local resource pool or the campus network resources[5].

(4) network management function. Test scores can be achieved statistical functions, the establishment of student file function, student certification function and fault detection function, etc.

\section{Conclusion}

There is no doubt that the establishment of network teaching platform of Public English teaching reform, play an important role in the establishment of new teaching mode. But to maintain a smooth and safe operation of the platform also need foreign language teachers, especially a large number of professional and technical personnel to carry out maintenance work. For example: update teaching materials, large-scale production of the courseware, the safety of the system maintenance work. Some jobs need not only understand the foreign language teaching and professional skills of the people can do, but at present this kind of compound talent less. In order to solve this problem, some school has established a special public network teaching research office (e.g., Shandong University) or computer assisted language teaching research, by teaching staff and technical staff together to form a team, division of labor cooperation completed maintenance work on the network platform. In fact, in the network teaching platform of everyday things, and a lot of work is the maintenance work platform. To maintain the normal operation of the teaching platform is more difficult than to create a platform for more challenging. The maintenance work is not in place, operation and safety of network platform will cause serious problems, which affects the effect of network teaching.

In conclusion, College English Network Teaching Based on the teaching platform development, teaching platform for network teaching provides tool support and technical support, also for the foreign language teachers to create the teaching style and reflect the opportunity to play to their wisdom. Although the network teaching is still in the exploratory stage, but it has created an open, autonomous learning and virtual teaching environment is changing the teaching methods and students' learning habits. The vivid, convenient, sharing, interaction and other characteristics of the network course won the general recognition of the students. It can be predicted, as a kind of modern education method, network teaching has broad application prospects.

\section{References}

[1] Gao liming, modern education technology [M]. Beijing: The Open University of China press, 1997.

[2] Hu Jiyue, Zhang Guoying, Shen Lanping, research on the teaching mode of the development of English network curriculum [J], foreign telephone teaching, 2003, 1, 12-15.

[3] Kong Wen, Li Qinghua, the concept of language teaching and Computer Assisted Language Teaching [J] foreign language telephone teaching, 2002, 2, 34-35.

[4] Zhuang Wei, Wu Min, Huang Wei, National College "new concept" College English network teaching pilot program [M]. Shanghai foreign language education press, 2004, 9.

[5] Zhang Hua, modern educational technology and foreign language teaching mode [J] foreign language telephone teaching, 2002, 1,48-50. 